\title{
Physical Factors to Evaluate the Servicescape of Theme Restaurants
}

\author{
Chih Jen Lee* ${ }^{1}$, Yu Chia Wang ${ }^{1,2}$ and Deng Chuan $\mathrm{Cai}^{3}$ \\ ${ }^{1}$ Ph.D. Candidate, Graduate School of Design, National Yunlin University of Science \& Technology, Taiwan, R.O.C. \\ ${ }^{2}$ Lecturer, Department of Communication Design, LingTung University, Taiwan, R.O.C. \\ ${ }^{3}$ Associate Professor, Department of Industrial Design, National Yunlin University of Science \& Technology, Taiwan, R.O.C.
}

\begin{abstract}
Theme restaurants are primarily run based on spatial planning, decor and entertainment arrangements, with a distinctive theme or specific style to attract consumers and create a value in the minds of consumers. However, after a rapid growth in popularity in the early to mid-1990s, theme restaurants began to lose market share, and many once popular brands were forced to downsize. This study explores the physical factors of theme restaurants that influence consumer perceptions to develop an assessment tool for the planning and design stage. First, various dimensions and facets were identified and developed into questionnaire items after referencing publicly available scales. The "Theme Restaurant Physical Factor Scale" was established after testing the pilot samples of 279 people and the official samples of 286 people. The analysis results indicate that a two-order confirmatory factor analysis of structural equation models is effective for verifying the theme restaurant physical factor scale. Among them, five latent variables, including aesthetics, ambient condition, space/function, seating comfort, and cleanliness, and 18 observable variables can be used as effective evaluation measurement indicators. The scale has relatively high reference value and can be applied to the restaurant industry and by designers for evaluation.
\end{abstract}

Keywords: servicescape; physical factors; theme restaurant; confirmatory factor analysis

\section{Introduction}

Consumers' product and service purchasing decisions depend not only on satisfaction with the "physical function," but also spiritual satisfaction with the "psychological function." Pine II and Gilmore (1999) contended that economic development is moving toward a new era. Economic behavior has focused on the stages of experience, which is beyond the traditional product and service selling method. With the evolution of consumption patterns, themed architectural spaces have begun to appear to satisfy different purchase behaviors and provide various intricately designed experiences.

Theme restaurants are primarily run based on spatial planning, decor and entertainment arrangements, with a distinctive theme or specific style to attract consumers and create a value in the minds of consumers. However, after a rapid growth in popularity in the early to mid-1990s, theme restaurants began to

\footnotetext{
*Contact Author: Chih Jen Lee, Ph.D. Candidate,

Graduate School of Design, National Yunlin University of Science and Technology, 123 University Road, Section 3, Douliou, Yunlin, Taiwan, R.O.C.

Tel: +886-4-727-5668 Fax: +886-4-723-1563

E-mail: g9430809@yuntech.edu.tw

(Received April 1, 2014 ; accepted October 15, 2014)
}

lose market share, and many once popular brands were forced to downsize (Weiss et al., 2004). According to the commerce and service industry census data, for every 100 restaurants, only $57.39 \%$ continued to operate after five years. The survival rate for restaurant sectors is significantly lower than the $70.82 \%$ for the entire service industry (Directorate-General of Budget, Accounting and Statistics, Executive Yuan, 2008), demonstrating the intensity of the competition.

Although the theme restaurant market currently provides numerous options, homogeneity is high, which increases the difficulty of operation. In order to increase profit by improving customer evaluation in service firms, most previous marketing research has focused on variable resources (e.g., recruiting, selecting, training, compensating, or motivating) on service employee personnel or service quality such as reliability, responsiveness, and empathy (Parasuraman et al., 1994; Zeithaml et al., 1996). Baker et al. (1992) indicated that when markets struggle to create advantages based on merchandise, pricing, promotion, and location, transforming the store environment becomes an ideal opportunity to create market differentiation. Kotler (1973) stated that the place, more specifically the atmosphere of the place, is more influential than the product itself in the purchase decision. Levitt (1981) found that when consumers 
assess intangible products (such as services), their evaluation is typically based on appearance and surface impressions. In other words, for dining services, the average consumer judges the physical aspects (such as the restaurant's appearance or interior decoration). Customers typically spend at least a moderate amount of time in the facility hoping to enjoy the decor and the employees' service in theme restaurants. The food usually takes a backseat to the theme, which is what these restaurants use to attract customers (Turley and Fugate, 1992). Therefore, physical factors in the servicescape not only affect the consumer's overall assessment of theme restaurants, but they are also important evidences.

When the environment atmosphere is used for commercial purposes, the planning direction and detail design are crucial for forecasting consumption. However, the design and decoration of the designer during the planning of theme restaurants must follow the traditional design criteria or be attached to the individual design style, with less consideration given to the preference of the target consumers. Engel et al. (1968) indicated that to understand consumer behavior, personal and situational factors must be examined. Kim and Moon (2009) also pointed out that the physical environment attributes in theme restaurants are likely to play a significant role in improving customers' perceptions and behaviors. Accordingly, to enhance professional service categories, study of spatial design must include the physical factors that shape consumers' perceptions. This study compiles related studies on servicescape, filters various physical factors, and establishes a "Theme Restaurant Physical Factor Scale." Furthermore, a two-order confirmatory factor analysis is used to analyze the scale's stability and goodness of fit, to verify whether the model applies to the "Theme Restaurant Physical Factor Scale" evaluation, and to provide feedback for design professionals and practical applications.

\section{Literature Review}

\subsection{The Theme-Oriented Dining Space}

Consumer space is the consumption context that is decorated to meet consumers' desires and needs (Sack, 1988). Space is no longer merely a traditional accommodation area; it also possesses the symbolic value of "atmosphere" and "meaning." If consumer space is discussed from this perspective, then space can be considered an integration of various signs or part of the product itself. Occasionally, space may even surpass the product and become the principal aspect. Therefore, space is becoming increasingly symbolic in numerous fields. The personality of a space can be shaped by various signs to present a context with a particular "theme" effect.

Theme restaurants are dining places decorated with a complex of distinctive signs that are independent from the eating and drinking activities (Beardsworth et al., 1999). This complex of distinctive signs is derived from a complete and identifiable narrative or concept of public culture. A restaurant's theme is not necessary associated with the type of meals it offers, Gottdiener (1997) takes three theme restaurants; Planet Hollywood, TGI Friday's and Hard Rock Café as examples, the dishes are salad, burgers, sandwiches, and grilled chicken wings. Compared to other American restaurants in any town in the United States, it is hard to distinguish which of several theme restaurants they are from. The impression remaining with consumers is the nostalgic atmosphere of the restaurant, an array of rock and roll musical instruments and memorable film world. Space designers transform this narrative or concept into an experience that enables consumers to perceive the theme.

\subsection{Relevant Dimensions of the Servicescape}

The initial definition and discussion of the service environment can be traced back to the $1950 \mathrm{~s}$. Martineau (1958) believed that applying the image concept to the retail field provided motivation for consumers' store selection decisions. Martineau referred to this motivational force as the store image, which was defined as how consumers mentally characterized a store. Kotler (1973) regarded atmosphere as environmental cues and argued that the consumer environment is designed to emit a unique atmospheric style and elicit a particular emotional response from the consumer. Kotler defined store atmosphere as designed retail areas. The primary goal is to manipulate consumer sentiment, by allowing consumers to purchase not just products, but also packaging, sales or post-sales services, and, most importantly, the atmosphere.

Based on a space-time background and evolving consumer needs, various scholars have adopted different foci regarding the service environment. Bitner (1992) compiled past studies and coined the term "servicescape" to describe how service providers use various physical factors in the environment to influence customer and employee behavior. Bitner defined servicescape as the physical environment which customers can experience, and classified three dimensions of the physical environment: 'ambient conditions,' 'spatial layout and functionality,' and 'signs, symbols and artifacts.' 'Ambient conditions' include background characteristics of the environment such as temperature, lighting, noise, music, and scent. 'Spatial layout' refers to the ways in which machinery, equipment, and furnishings are arranged, the size and shape of those items, and the spatial relationships among them. 'Functionality' refers to the ability of the same items to facilitate performance and the accomplishment of goals. 'Signs, symbols, and artifacts' displayed on the exterior and interior of a structure are examples of explicit communicators. For consumers, the servicescape can provide clues and create an immediate perceptive impression, but also on 
Table 1. Prior Research on the Servicescape Dimensions

\begin{tabular}{|c|c|c|}
\hline Author & Servicescape dimensions & Attributes \\
\hline Bitner (1992) & $\begin{array}{l}\text { 1. Ambient conditions } \\
\text { 2. Space/Function } \\
\text { 3. Signs, Symbols and Artifacts }\end{array}$ & $\begin{array}{l}\text { 1. Temperature, air quality, noise, music, and odor } \\
\text { 2. Layout, equipment, and furnishings } \\
\text { 3. Signage, personal artifacts, and style of décor }\end{array}$ \\
\hline Wakefield and Blodgett (1994) & $\begin{array}{l}\text { 1. Spatial layout \& functionality } \\
\text { 2. Aesthetics }\end{array}$ & $\begin{array}{l}\text { 1. Stadium seats, ticket windows/gates, hallways/walkways, } \\
\text { entrances/exits, food service areas, and rest-rooms (men's) } \\
\text { 2. External environment, exterior construction, interior } \\
\text { construction, score-boards, and facility cleanliness }\end{array}$ \\
\hline Wakefield and Blodgett (1996) & $\begin{array}{l}\text { 1. Layout accessibility } \\
\text { 2. Facility aesthetics } \\
\text { 3. Seating comfort } \\
\text { 4. Electric equipment / displays } \\
\text { 5. Cleanliness }\end{array}$ & $\begin{array}{l}\text { 1. Layout of exit and entry, furnishing, and equipment layout } \\
\text { 2. Architectural design, color, and interior design } \\
\text { 3. Physical seat and space of seat } \\
\text { 4. Signs, symbols, and artifacts for leisure experience } \\
\text { 5. Facility cleanliness }\end{array}$ \\
\hline Wakefield and Blodgett (1999) & $\begin{array}{l}\text { 1. Building design and décor } \\
\text { 2. Equipment } \\
\text { 3. Ambience }\end{array}$ & $\begin{array}{l}\text { 1. Outside appearance, interior design, layout, and seats } \\
\text { 2. Electric equipment } \\
\text { 3. Cleanliness, temperature, and neatness of employees' } \\
\text { appearance }\end{array}$ \\
\hline Lucas (2003) & $\begin{array}{l}\text { 1. Layout navigation } \\
\text { 2. Cleanliness } \\
\text { 3. Seating comfort } \\
\text { 4. Interior décor } \\
\text { 5. Ambience }\end{array}$ & $\begin{array}{l}\text { 1. Architecture, interior design, and spatial layout } \\
\text { 2. Clean slot floor } \\
\text { 3. Padding, backrests, fabric/heat-dissipating seat, and } \\
\text { uncrowded seat } \\
\text { 4. Lighting, color, and floor décor } \\
\text { 5. Internal climate, music, and visual graphic }\end{array}$ \\
\hline Newman (2007) & $\begin{array}{l}\text { 1. Space } \\
\text { 2. Way-findings }\end{array}$ & $\begin{array}{l}\text { 1. Spatial density } \\
\text { 2. Legibility of internal design such as central passageways } \\
\text { and meeting places }\end{array}$ \\
\hline Ryu and Jang (2008) & $\begin{array}{l}\text { 1. Facility aesthetics } \\
\text { 2. Lighting } \\
\text { 3. Ambience } \\
\text { 4. Layout } \\
\text { 5. Dining equipment }\end{array}$ & $\begin{array}{l}\text { 1. Architectural design, color, and interior design } \\
\text { 2. Type of lighting and illumination } \\
\text { 3. Music, temperature, and scent } \\
\text { 4. Object (e.g., machinery, equipment, and furnishings) layout } \\
\text { 5. High-quality flatware, china, glassware, and linen }\end{array}$ \\
\hline Edwards and Gustafsson (2008) & $\begin{array}{l}\text { 1. Internal variables } \\
\text { 2. Layout and design }\end{array}$ & $\begin{array}{l}\text { 1. Music, noise, and odor } \\
\text { 2. Table layout and seating }\end{array}$ \\
\hline Kim and Moon (2009) & $\begin{array}{l}\text { 1. Ambient condition } \\
\text { 2. Facility aesthetics } \\
\text { 3. Layout } \\
\text { 4. Electric equipment } \\
\text { 5. Seating comfort }\end{array}$ & $\begin{array}{l}\text { 1. Lighting level, temperature, aroma, and background music } \\
\text { 2. Architecture, interior, décor, color, and overall attractiveness } \\
\text { 3. Tables, service areas, and passageways } \\
\text { 4. Audio/video equipment } \\
\text { 5. Comfortable seat and uncrowded seat }\end{array}$ \\
\hline Lee and Kim (2014) & $\begin{array}{l}\text { 1. Attractiveness } \\
\text { 2. Cleanliness } \\
\text { 3. Layout } \\
\text { 4. Comfort }\end{array}$ & $\begin{array}{l}\text { 1. Finishes, colors, and facilities } \\
\text { 2. Clean facilities, entrances, corridors, and restrooms } \\
\text { 3. Easy access to designated places } \\
\text { 4. Comfortable air, temperature, and brightness }\end{array}$ \\
\hline
\end{tabular}

the surrounding environment to form beliefs as a basis to infer service quality.

Relevant scholars have supported the perspective proposed by Bitner (1992). Wakefield and Blodgett (1994) used Major League Baseball (MLB) stadiums as research subjects and classified servicescape elements into two aspects: (1) spatial layout and functionality; and (2) elements related to aesthetic appeal. Lee and Kim (2014) found that servicescape (attractiveness, cleanliness, layout, and comfort) influenced perceived quality, which resulted in higher satisfaction. As shown in Table 1., scholars have different suggestions regarding the attribute foci of various industries.

\section{Research Methodology}

\subsection{Pre-Test Version of Scale Construction}

The research tools used in this study included an onsite self-administered questionnaire comprising two sections, the physical factors of the theme restaurant servicescape and respondents' personal socioeconomic background. The theme restaurant servicescape physical factor scale was based on prior work. The contents of the scale were reviewed by three spatial design doctoral researchers and two spatial design professionals (practical experiences for 11 and 15 years) to assess the goodness of fit of the questionnaire regarding its descriptions, concepts, meanings, and application value. The questionnaire comprised 22 questions (Table 2.). A five-point Likert scale, which ranged from 1 point for "very dissatisfied" to 5 points for "very satisfied," was adopted. The respondents' socioeconomic background information included gender, age, education level, occupation, and allowance.

\subsection{Pre-Test Version of Scale Pilot Test}

Taichung is located in central Taiwan; the population growth rate is the first among three other major 
Table 2. The Dimensions of the Theme Restaurants Servicescape

\begin{tabular}{|c|c|c|}
\hline Dimensions & Variables & Author \\
\hline Aesthetics & $\begin{array}{l}\text { This restaurant's architecture gives it an attractive character. } \\
\text { This restaurant's interior décor is decorated in an attractive style. } \\
\text { This restaurant's style meets the theme. } \\
\text { The use of artifacts in the décor scheme adds excitement to this theme restaurant } \\
\text { environment. } \\
\text { This restaurant is painted in attractive colors. }\end{array}$ & $\begin{array}{l}\text { Bitner (1992); Wakefield } \\
\text { and Blodgett (1996); } \\
\text { Wakefield and Blodgett } \\
(1999) ; \text { Ryu and Jang } \\
(2008)\end{array}$ \\
\hline $\begin{array}{l}\text { Ambient } \\
\text { conditions }\end{array}$ & $\begin{array}{l}\text { The temperature in this restaurant is comfortable. } \\
\text { The aroma in this restaurant is pleasant. } \\
\text { - The background music, played overhead, makes a more enjoyable place. } \\
\text { - This restaurant does not have the noise of the outdoors or indoors. } \\
\text { - The overall lighting level in this restaurant's environment is appropriate. }\end{array}$ & $\begin{array}{l}\text { Lucas (2003); Ryu and } \\
\text { Jang (2008); Edwards and } \\
\text { Gustafsson (2008); Kim } \\
\text { and Moon (2009) }\end{array}$ \\
\hline $\begin{array}{l}\text { Space / } \\
\text { Function }\end{array}$ & $\begin{array}{l}\text { The seating between neighbors is well spaced out. } \\
\text { The aisles between the tables are wide enough to pass through easily. } \\
\text { The signs in this restaurant provide adequate direction and help you find your way. } \\
\text { Overall, this facility's layout makes it easy to get where you want to go. } \\
\text { The audio/video machines add excitement to the place. } \\
\text { Exquisite tableware adds dining atmosphere. }\end{array}$ & $\begin{array}{l}\text { Bitner (1992); Wakefield } \\
\text { and Blodgett (1996); Lucas } \\
\text { (2003); Newman (2007); } \\
\text { Kim and Moon (2009) }\end{array}$ \\
\hline $\begin{array}{l}\text { Seating } \\
\text { comfort }\end{array}$ & $\begin{array}{l}\text { The chairs allow me to sit at a comfortable distance from the table. } \\
\text { It is easy to get in and out of the seats at this theme restaurant. } \\
\text { This theme restaurant's seats are comfortable. }\end{array}$ & $\begin{array}{l}\text { Lucas }(2003) ; \text { Ryu and } \\
\text { Jang }(2008) ; \text { Kim and } \\
\text { Moon (2009) }\end{array}$ \\
\hline Cleanliness & $\begin{array}{l}\text { Employees are neat in appearance. } \\
\text { This theme restaurant maintains clean restrooms. } \\
\text { Overall, this theme restaurant is kept clean. }\end{array}$ & $\begin{array}{l}\text { Wakefield and Blodgett } \\
\text { (1996); Wakefield and } \\
\text { Blodgett (1999); Lucas } \\
\text { (2003) }\end{array}$ \\
\hline
\end{tabular}

metropolitan areas (Taipei, Taichung and Kaohsiung). Due to the rising and flourishing economy, requests concerning dining quality for clients are higher than ever in the area. The theme restaurants on MuseumPark Avenue, which have highly integrated multiple design elements and materials, have created exotic and nostalgic dining spaces in recent years. There are nearly 40 theme restaurants located on both sides of the street over a distance of 650 meters, which is the highest density in the area (see Fig.1.). The research populations were consumers of theme restaurants on Museum-Park Avenue in Taichung.

Data were collected during four holiday periods between May 13, 2011, and June 5, 2011. The Poll Center of Chienkuo Technology University (Taiwan) was commissioned to conduct the survey. Additionally, 8 professional interviewers were evenly spaced in pairs (approximately 150 meters apart) on the street where theme restaurants were located to survey consumers who had finished dining. The interviewees were initially asked whether they would participate in the survey. If they refused, the interviewers approached the next candidate. When the interviewee's response was unclear, the interviewers provided further guidance. A total of 285 questionnaires were collected. After eliminating the questionnaires that were more than onethird incomplete (regarded as invalid questionnaires), 279 valid questionnaires remained, for an effective recovery rate of $97.8 \%$ (see a description of the sample characteristics in Table 3.).

\subsection{Pre-Test Version of Scale Analysis}

The primary goal of the exploratory factor analysis (EFA) is to assess the pros and cons of the foregoing questionnaire items. The KMO value for the Pre-Test Version of Scale was 0.862 and the $p$ value for the
Table 3. Demographic Characteristics of Participants ( $\mathrm{N}=279)$

\begin{tabular}{llrr}
\hline Characteristics & Category & $\mathrm{N}$ & \multicolumn{1}{c}{$\%$} \\
\hline Gender & Male & 142 & 50.9 \\
& Female & 137 & 49.1 \\
Education Level & Junior High and below & 1 & 0.4 \\
& Senior High & 52 & 18.6 \\
& College & 185 & 66.3 \\
& Graduate and above & 41 & 14.7 \\
Allowance & US\$ 330 and below & 39 & 14.0 \\
& US\$ 331 600 & 75 & 26.9 \\
& US\$ 601 1515 & 130 & 46.6 \\
& US\$ 1516 3030 & 27 & 9.7 \\
Age & US\$ 3031 and above & 8 & 2.9 \\
& 19 and below & 16 & 5.7 \\
& 20 29 & 99 & 35.5 \\
& 30 39 & 113 & 40.5 \\
& $40 \sim 49$ & 43 & 15.4 \\
& 50 and above & 8 & 2.9 \\
& Student & 62 & 22.2 \\
Occupation & Public Servant and Teacher & 30 & 10.8 \\
& Service Industry & 95 & 34.1 \\
& Unemployed & 29 & 10.4 \\
& Manufacturing Industry & 20 & 7.2 \\
& Professional Jobs & 35 & 12.5 \\
& Others & 8 & 2.9 \\
\hline
\end{tabular}

Bartlett spherical test was less than 0.001, indicating that the factor extraction was appropriate for this study (Kaiser, 1974). Subsequently, we adopted principal component analysis with a varimax orthogonal rotation to obtain an eigenvalue greater than 1; and a loading of 0.5 was used as the critical value for deleting questions (Lederer and Sethi, 1991). According to the analysis results, six main factors were extracted from 22 questions. By assessing the factor content, we found 
Table 4. Results of Exploratory Factor Analysis

\begin{tabular}{l}
\hline Factors and items \\
\hline Factor 1: Aesthetics (Eigenvalue=2.995, Variance $=16.639 \%$, Alpha =0.864) \\
(A1) This restaurant's architecture gives it an attractive character. \\
(A2) This restaurant's interior décor is decorated in an attractive style. \\
(A3) This restaurant's style meets the theme. \\
(A4) This restaurant is painted in attractive colors. \\
Factor 2: Ambient condition (Eigenvalue=2.497, Variance $=13.874 \%$, Alpha =0.776) \\
(E1) The temperature in this restaurant is comfortable. \\
(E2) The aroma in this restaurant is pleasant. \\
(E3) The background music, played overhead, makes this restaurant a more enjoyable place. \\
(E4) The overall lighting level in this restaurant environment is appropriate. \\
Factor 3: Space / function (Eigenvalue=2.782, Variance =15.457\%, Alpha =0.845) \\
(F1) In this theme restaurant, the seating between neighbor are well spaced out. \\
(F2) In this theme restaurant, the aisles between the tables are wide enough to pass through easily. \\
(F3) The signs in this restaurant environment provide adequate direction and help you find your way. \\
(F4) Exquisite tableware adds dining atmosphere. \\
Factor 4: Seating comfort (Eigenvalue=1.980, Variance =10.998\%, Alpha =0.707) \\
(S1) This theme restaurant's chairs allow me to sit at a comfortable distance from the table. \\
(S2) It is easy to get in and out of the seats at this theme restaurant. \\
(S3) This theme restaurant's seats are comfortable. \\
Factor 5: Cleanliness (Eigenvalue=2.564, Variance =14.245\%, Alpha =0.930) \\
(C1) Employees are neat in appearance. \\
(C2) This theme restaurant maintains clean restrooms. \\
(C3) Overall, this theme restaurant is kept clean.
\end{tabular}

that item distribution generally conforms to the five dimensions of design during the planning stage. After the questionnaire items were reviewed sequentially, items with an independent factor or low loading, such as "The use of artifacts in the décor scheme adds excitement to this theme restaurant's environment," "This restaurant does not have the noise of the outdoors or indoors," or "proper arrangements," "Overall, this facility's layout makes it easy to get where you want to go," and "The audio/video machines add excitement to the place" were excluded. During this stage, 4 items were eliminated and 18 items were retained in the formal scale. The factor analysis and associated statistics are presented in Table 4. Combined factor loadings accounted for $71.211 \%$ of the total variance in the factor pattern.

\subsection{Formal Scale Measurement}

Hinkin (1998) argued that when developing a new scale, various samples must be collected to implement EFA and confirmatory factor analysis (CFA) to confirm whether the measurement items accurately indicate the corresponding factors and the stability of the test factor structure. During the pilot test stage, five stable factors in the scale were identified using EFA. During the formal measurement, structure equation modeling (SEM) was used to analyze various factors obtained from EFA and the relationship stability between variables. The physical factor scale used in this study is shown in Fig.1.

The data collection method was identical to that used in the pilot test stage. Data were collected on the four weekends (including Friday nights) between June 24, 2011, and July 17, 2011. We collected 300

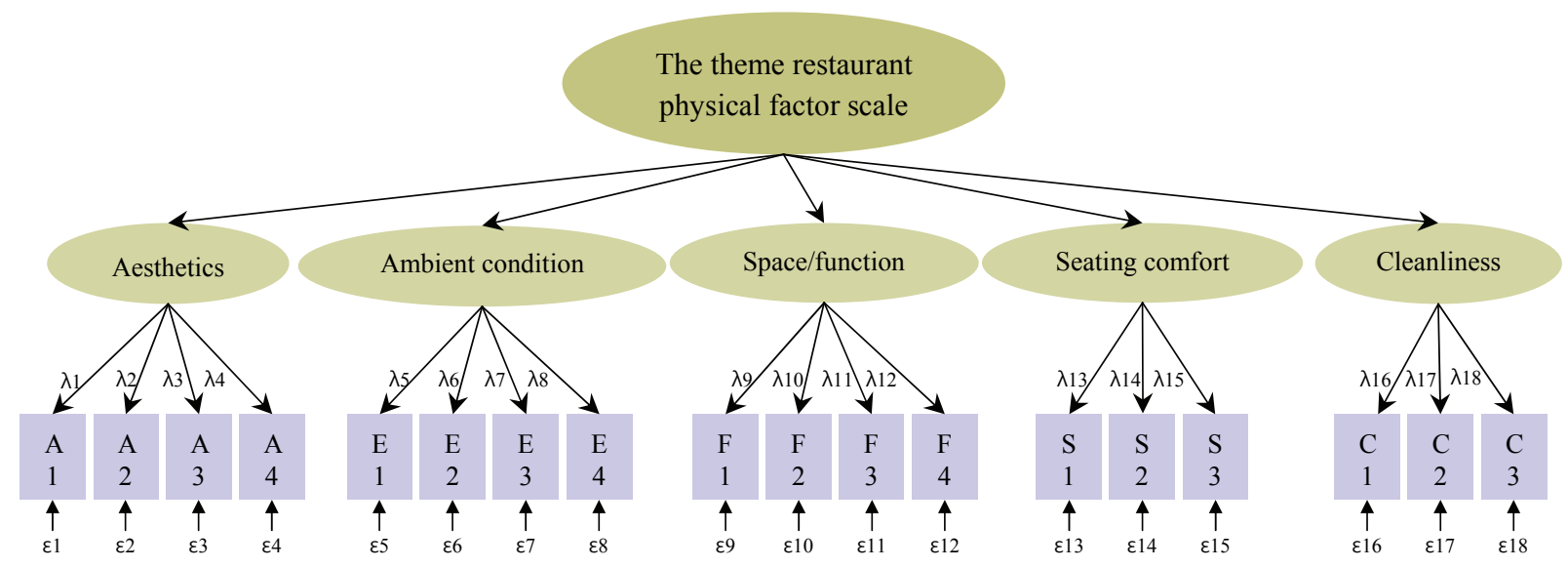

Fig.1. Two-Order Confirmatory Factor Analysis of the Theme Restaurant Physical Factor Scale 
questionnaires; after deleting 14 incomplete responses, 286 surveys were used for final analysis $(95.3 \%$ response rate). Table 5. summarizes the demographic profile of the respondents.

Table 5. Demographic Characteristics of Participants $(\mathrm{N}=286)$

\begin{tabular}{|c|c|c|c|}
\hline Characteristics & Category & $\mathrm{N}$ & $\%$ \\
\hline \multirow[t]{2}{*}{ Gender } & Male & 177 & 61.9 \\
\hline & Female & 109 & 38.1 \\
\hline \multirow[t]{4}{*}{ Education Level } & Junior High and below & 2 & 0.7 \\
\hline & Senior High & 59 & 20.6 \\
\hline & College & 188 & 65.7 \\
\hline & Graduate and above & 37 & 12.9 \\
\hline \multirow[t]{5}{*}{ Allowance } & US\$ 330 and below & 48 & 16.8 \\
\hline & US\$ 331 600 & 82 & 28.7 \\
\hline & US\$ $601 \sim 1515$ & 124 & 43.4 \\
\hline & US\$ 1516 3030 & 23 & 8.0 \\
\hline & US\$ 3031 and above & 9 & 3.1 \\
\hline \multirow[t]{5}{*}{ Age } & 19 and below & 24 & 8.4 \\
\hline & $20 \sim 29$ & 106 & 37.1 \\
\hline & $30 \sim 39$ & 111 & 38.8 \\
\hline & $40 \sim 49$ & 41 & 14.3 \\
\hline & 50 and above & 4 & 1.4 \\
\hline \multirow[t]{7}{*}{ Occupation } & Student & 71 & 24.8 \\
\hline & Public Servant and Teacher & 28 & 9.8 \\
\hline & Service Industry & 101 & 35.3 \\
\hline & Unemployed & 31 & 10.8 \\
\hline & Manufacturing Industry & 18 & 6.3 \\
\hline & Professional Jobs & 26 & 9.1 \\
\hline & Others & 11 & 3.8 \\
\hline
\end{tabular}

\section{Results}

This study employed LISREL 8.8 software to process the CFA statistics. However, before conducting statistical analysis using LISREL, the data characteristics were fully examined to ensure compliance with the SEM assumption and to avoid influencing the model assessment and test results. For the 286 samples examined in this study, the skewness values ranged from -1.102 to -0.553 , with the absolute value less than the extreme value of 3 . The kurtosis values ranged from -0.532 to 1.021 , with the absolute value less than the extreme value of 10 , conforming to the variable distribution standard (Kline, 1988). Therefore, we implemented the maximum likelihood model and adopted the suggestions of Bagozzi and Yi (1988) to evaluate the goodness of fit of the model regarding preliminary fit criteria, overall model fit, and fit of internal structure of the model.

\subsection{Preliminary Fit Criteria Test of the Theme Restaurant Physical Factor Scale}

This study adopted the following three criteria for assessing the preliminary fit criteria: (1) the standardized coefficients must be between 0.45 to 0.95 ; (2) no negative error variances are present and all error variances must meet the level of significance ( $t$ values $>1.96$ ); and (3) no very large standard errors are observed (Bentler and $\mathrm{Wu}, 1993$ ).
As shown in Table 6., the standardized coefficients ranged from 0.70 to 0.91 , which exceeds the 0.45 standard without negative error variances. Additionally, the $t$ value exceeded 1.96, meeting the 0.05 level of significance. The standard errors ranged between 0.043 and 0.063 , indicating that the standard errors were relatively small. Under the theoretical mode of this study, the preliminary fit criteria were fully established.

Table 6. Preliminary Fit Criteria of the Theme Restaurant Physical Factor Scale

\begin{tabular}{ccccc}
\hline $\begin{array}{c}\text { Observed } \\
\text { Variables }\end{array}$ & $\begin{array}{c}\text { Standardized } \\
\text { Coefficient }\end{array}$ & $\begin{array}{c}\text { Error } \\
\text { Variances }\end{array}$ & $t$ value & $\begin{array}{c}\text { Standard } \\
\text { Errors }\end{array}$ \\
\hline A1 & 0.81 & 0.34 & -- & -- \\
A2 & 0.91 & 0.17 & 17.32 & 0.045 \\
A3 & 0.71 & 0.50 & 12.87 & 0.048 \\
A4 & 0.77 & 0.41 & 14.31 & 0.047 \\
E1 & 0.71 & 0.49 & -- & -- \\
E2 & 0.84 & 0.29 & 12.23 & 0.053 \\
E3 & 0.71 & 0.50 & 10.76 & 0.054 \\
E4 & 0.74 & 0.45 & 11.20 & 0.051 \\
F1 & 0.83 & 0.31 & -- & -- \\
F2 & 0.72 & 0.49 & 12.85 & 0.043 \\
F3 & 0.86 & 0.26 & 15.83 & 0.045 \\
F4 & 0.70 & 0.50 & 12.59 & 0.050 \\
S1 & 0.72 & 0.48 & -- & -- \\
S2 & 0.71 & 0.49 & 10.30 & 0.051 \\
S3 & 0.82 & 0.33 & 10.81 & 0.056 \\
C1 & 0.76 & 0.42 & -- & -- \\
C2 & 0.83 & 0.31 & 11.14 & 0.063 \\
C3 & 0.71 & 0.50 & 10.70 & 0.057 \\
\hline
\end{tabular}

\subsection{Overall Model Fit Test of the Theme Restaurant Physical Factor Scale}

Table 7. Overall Model Fit of the Theme Restaurant Physical Factor Scale

\begin{tabular}{|c|c|c|}
\hline Index & Criteria & Results \\
\hline \multicolumn{3}{|c|}{ Absolute Fit Measures } \\
\hline$\chi^{2}(\mathrm{p})$ & Non-significant & $\mathrm{p}=0.00003$ \\
\hline$\chi^{2} / \mathrm{df}$ & $<3$ & 1.58 \\
\hline GFI & $>0.9$ & 0.93 \\
\hline AGFI & $>0.9$ & 0.90 \\
\hline RMR & $<0.05$ & 0.032 \\
\hline SRMR & $<0.05$ & 0.050 \\
\hline RMSEA & $<0.08$ & 0.045 \\
\hline \multicolumn{3}{|c|}{ Relative Fit Measures } \\
\hline CFI & $>0.9$ & 0.98 \\
\hline NFI & $>0.9$ & 0.95 \\
\hline NNFI & $>0.9$ & 0.98 \\
\hline IFI & $>0.9$ & 0.98 \\
\hline RFI & $>0.9$ & 0.94 \\
\hline \multicolumn{3}{|c|}{ Parsimonious Fit Measures } \\
\hline PNFI & $>0.5$ & 0.81 \\
\hline PGFI & $>0.5$ & 0.70 \\
\hline $\mathrm{CN}$ & $>200$ & 242.30 \\
\hline AIC & $\begin{array}{l}<\text { Independence AIC } \\
<\text { Saturated AIC }\end{array}$ & $\begin{array}{l}\text { Model AIC }=287.81 \\
\text { Independence AIC }=4290.91 \\
\text { Saturated AIC }=342.00\end{array}$ \\
\hline
\end{tabular}


The overall model fit test was employed to evaluate the goodness of fit of the entire model and the observed data, and can be considered as the external quality evaluation of the model. This study referenced the guidelines provided by Jöreskög and Sörbom (1993), and used absolute fit measures, relative fit measures, and parsimonious fit measures to describe the overall model fit. Table 7 . shows that $p<0.1$ is significant, and the $\chi^{2}$ test is influenced by the size of the sample numbers. Therefore, the $\chi^{2} / \mathrm{df}$ assessment model is a more appropriate indicator to assess the model's goodness of fit. Related studies have recommended using no more than 2 or 3 for the standard (Hoyle, 1995; Chin and Todd, 1995). The $\chi^{2} / \mathrm{df}$ ratio for this model was $205.81 / 130=1.58$, which agrees with the recommended values. Overall, the physical factor scale analysis model constructed in this study approached a goodness of fit.

\subsection{Fit of Internal Structure of Model Test of the} Theme Restaurant's Physical Factor Scale

A fit of the internal structure of the model test was used to evaluate the reliability of the observable variables and latent variables and the level of significance of the estimated parameters. This can be considered the internal quality evaluation in this model. Bagozzi and Yi (1988) recommended the following standards for an ideal fit of the internal structure of the model: (1) the individual item reliability $\left(\mathrm{R}^{2}\right)$ is greater than 0.50 ; (2) the composite reliability (CR) for individual latent variables is greater than 0.60 ; and (3) the average variance extracted (AVE) for the latent variable is greater than 0.50 .

Table 8 . shows that the reliability of the observable variables ranged between 0.50 and 0.83 , with 18 variables exceeding 0.5 , indicating good reliability for the measurement indicators of this study. The composite reliability for latent variables ranged between 0.80 and 0.88 , with five latent variables exceeding 0.6 ,

Table 8. Fit of the Internal Structure of the Model of the Theme Restaurant's Physical Factor Scale

\begin{tabular}{lcccc}
\hline $\begin{array}{l}\text { Latent } \\
\text { Variables }\end{array}$ & $\begin{array}{l}\text { Observable } \\
\text { Variables }\end{array}$ & $\mathrm{R}^{2}$ & $\mathrm{CR}$ & $\mathrm{AVE}$ \\
\hline Aesthetics & $\mathrm{A} 1$ & 0.66 & 0.88 & 0.65 \\
& $\mathrm{~A} 2$ & 0.83 & & \\
& $\mathrm{~A} 3$ & 0.50 & & \\
& $\mathrm{~A} 4$ & 0.59 & & \\
Ambient & $\mathrm{E} 1$ & 0.51 & 0.84 & 0.57 \\
condition & $\mathrm{E} 2$ & 0.71 & & \\
& $\mathrm{E} 3$ & 0.50 & & \\
& $\mathrm{E} 4$ & 0.55 & & \\
Space / & $\mathrm{F} 1$ & 0.69 & 0.86 & 0.61 \\
function & $\mathrm{F} 2$ & 0.51 & & \\
& $\mathrm{~F} 3$ & 0.74 & & \\
& $\mathrm{~F} 4$ & 0.50 & & \\
Seating & $\mathrm{S} 1$ & 0.52 & 0.80 & 0.57 \\
comfort & $\mathrm{S} 2$ & 0.51 & & \\
& $\mathrm{~S} 3$ & 0.67 & & \\
Cleanliness & $\mathrm{C} 1$ & 0.58 & 0.81 & 0.59 \\
& $\mathrm{C} 2$ & 0.69 & & \\
& $\mathrm{C} 3$ & 0.50 & & \\
\hline
\end{tabular}

indicating good internal consistency. The AVE values ranged between 0.57 and 0.65 , with all five dimensions exceeding 0.5 , indicating that the latent variable measurements had good variation explanation.

\section{Conclusion}

This study explores the physical factors of theme restaurants that influence consumer perceptions to develop an assessment tool for the planning and design stage. The "Theme Restaurant Physical Factor Scale" was established after testing the pilot samples of 279 people and the official samples of 286 people. The analysis results indicate that a two-order confirmatory factor analysis of structural equation models is effective for verifying the theme restaurant physical factor scale. Among them, five latent variables, including aesthetics, ambient condition, space / function, seating comfort, and cleanliness, and 18 observable variables can be used as effective evaluation measurement indicators. The scale has a relatively high reference value and can be applied to the restaurant industry and by designers for evaluation.

Regarding planning and design, the environmental space is an area to display products and enhance product value. The problems faced by designers are often poorly defined. Typically, designers are instructed to design spaces that "have appropriate usable areas and a pleasant appearance," which is general and unspecific. Therefore, the ability to successfully solve design problems depends on whether the problems can be identified from among the general confusion, which is also known as the demand for clarity. However, the demand clarity cannot be determined by the theme restaurant industry or the designer alone; it must be based on a consensus between both sides. According to empirical evidence, the theme restaurant physical factor scale developed in this study is appropriate for both theme restaurant manager and designer to reach a consensus on design guidelines.

The physical factors of the servicescape play a strategic role in the operation of theme restaurants (Table 9.). The results of the survey can be used as a guideline: in terms of aesthetics, to convey the characteristics of the consumer space through the shapes, lines, proportions, and colors of the architecture and interior design; in terms of ambient condition, to use temperature, smell, music, and overall illumination to create the appropriate atmosphere that allows consumers to experience the theme through their sensory perceptions; in terms of space/function, to appropriately configure the traffic flow connections of the dining area with other areas to meet consumers' needs; in terms of seating comfort, to provide comfortable seating to promote diverse activities, such as talking, dining, and relaxation; in terms of cleanliness, to maintain clean and tidy field facilities, and ensure staff have a clean appearance and appropriate work clothes that reflect the overall image of the restaurant.

The reasons consumers visit theme restaurants are diverse. Although the servicescape plays a key role in attracting consumers, other aspects, such as the food 
Table 9. The Definition of Physical Factors

\begin{tabular}{ll}
\hline Dimensions & Definition \\
\hline Aesthetics & Aesthetics are a function of \\
architectural design, as well \\
as interior design and décor, \\
both of which contribute \\
to the attractiveness of the \\
servicescape. \\
Ambient \\
conditions \\
Ambience means intangible \\
background characteristics \\
that tend to affect the non- \\
visual senses and may have \\
a subconscious effect on \\
customers. \\
Function \\
Spatial refers to the ways \\
in which m a chine ry, \\
equipment, and furnishings \\
are arranged, and the spatial \\
relationships among them. \\
Functionality refers to the \\
ability of the same items to \\
facilitate performance and the \\
accomplishment of goals. \\
Seating comfort is affected by \\
both the physical seat itself \\
and by the space between the \\
seats. \\
By order, straighten and \\
clean, so employees and \\
facilities are presented in a \\
systemic arrangement.
\end{tabular}

quality and cost, also have a considerable influence. In other words, although the servicescape may be a necessary condition for stimulating consumers' purchasing decisions, it is not a sufficient condition. Future studies should explore, examine, and compare related issues, such as food quality and pricing/value, to provide a comprehensive understanding of the servicescape and food quality.

\section{References}

1) Bagozzi, R. P. and Yi, Y. (1988) On the evaluation of structural equation models. Journal of the Academy of Marketing Science, 16(1), pp.74-94.

2) Baker, J., Levy, M., and Grewal, D. (1992) An experimental approach to making retail store environmental decisions. Journal of Retailing, 68(4), pp.445-460.

3) Beardsworth, A. and Bryman, A. (1999) Late modernity and the dynamics of quasification: The case of the themed restaurant. The Sociological Review, 47(2), pp.228-257.

4) Bentler, P. M. and Wu, E. J. C. (1993) EQS for Windows user's guide. Encino, CA: Multivariate Software, Inc.

5) Bitner, M. J. (1992) Servicescapes: The impact of physical surroundings on customers and employees. Journal of Marketing, 56(2), pp.57-71.

6) Chin, W. W. and Todd, P. A. (1995) On the use, usefulness, and ease of use of structural equation modeling in MIS research: A note of caution, MIS Quarterly, 19(2), pp.237-246.

7) Directorate-General of Budget, Accounting and Statistics. (2008) 2006 Industry, commerce and service census. Taipei: Executive Yuan.

8) Edwards, J. S. A. and Gustafsson, I.-B. (2008) The room and atmosphere as aspects of the meal: A review. Journal of Foodservice, 19(1), pp.22-34.

9) Engel, J. F., Kollat, D. T., and Blackwell, R. D. (1968) Consumer Behavior (5th ed.). New York: Holt, Rinehart and Winston.
10) Gottdiener, M. (1997) The theming of America: Dreams, visions, and commercial spaces. Boulder, CO: Westview Press.

11) Hinkin, T. R. (1998) A brief tutorial on the development of measures for use in survey questionnaires. Organizational Research Methods, 1(1), pp.104-121.

12) Hoyle, R. H. (1995) Structural equation modeling: Concepts, issues, and applications. Thousand Oaks, CA: SAGE Publications.

13) Jöreskög, K. G. and Sörbom, D. (1993) LISREL: Structural equation modeling with the SIMPLIS command language. Chicago, IL: Scientific Software International.

14) Kaiser, H. F. (1974) An index of factorial simplicity. Psychometrika, 39(1), pp.31-36.

15) Kim, W. G. and Moon, Y. J. (2009) Customers' cognitive, emotional, and actionable response to the servicescape: A test of the moderating effect of the restaurant type. International Journal of Hospitality Management, 28(1), pp.144-156.

16) Kline, R. B. (1998) Principles and practice of structural equation modeling. New York: The Guilford Press.

17) Kotler, P. (1973) Atmospherics as a Marketing Tool. Journal of Retailing, 49(4), pp.48-64.

18) Lederer, A. L. and Sethi, V. (1991) Critical dimensions of strategic information systems planning. Decision Sciences, 22(1), pp.104119

19) Lee, S. Y. and Kim, J. H. (2014) Effects of servicescape on perceived service quality, satisfaction and behavioral outcomes in public service facilities. Journal of Asian Architecture and Building Engineering, 13(1), 125-131.

20) Levitt, T. (1981) Marketing intangible products and product intangibles. Harvard Business Review, 59(3), pp.94-102.

21) Lucas, A. F. (2003) The determinants and effects of slot servicescape satisfaction in a Las Vegas hotel casino. UNLV Gaming Research and Review Journal, 7(1), pp.1-17.

22) Martineau, P. (1958) The personality of the retail store. Harvard Business Review, 52(1), pp.47-55.

23) Newman, A. J. (2007) Uncovering dimensionality in the servicescape: Towards legibility. The Service Industries Journal, 27(1), pp.15-28.

24) Parasuraman, A., Zeithaml, V. A., and Berry, L. L. (1994) Alternative scales for measuring service quality: A comparative assessment baked on psychometric and diagnostic criteria. Journal of Retailing, 70(3), pp.201-230.

25) Pine II, B. J. and Gilmore, J. H. (1999) The experience economy: Work is theatre \& every business a stage. Boston, MA: Harvard Business School Press.

26) Ryu, K. and Jang, S. (2008) Influence of restaurant's physical environments on emotion and behavioral intention, The Service Industries Journal, 28(8), pp.1151-1165.

27) Sack, R. D. (1988) The consumer's world: Place as context. Annals of the Association of American Geographers, 78(4), pp.642-666.

28) Turley, L. W. and Fugate, D. L. (1992) The multidimensional nature of service facilities: viewpoints and recommendations. The Journal of Services Marketing, 6(3), pp.37-53.

29) Wakefield, K. L. and Blodgett, J. G. (1994) The importance of servicescape in leisure service settings. Journal of Services Marketing, 8(3), pp.66-76.

30) Wakefield, K. L. and Blodgett, J. G. (1996) The effect of the servicescape on customers' behavioral intentions in leisure service setting. Journal of Services Marketing, 10(6), pp.45-61.

31) Wakefield, K. L. and Blodgett, J. G. (1999) Customer response to intangible and tangible service factors. Psychology \& Marketing, 16(1), pp.51-68.

32) Weiss, R., Feinstein, A. H., and Dalbor, M. C. (2004) Customer satisfaction of theme restaurant attributes and their influence on return intent. Journal of Foodservice Business Research, 7(1), pp.23-42.

33) Zeithaml, V. A., Berry, L. L., and Parasuraman, A. (1996) The behavioral consequences of service quality. Journal of Marketing, 60(2), pp.31-46 